\title{
THE FAMILY - A BIOLOGICAL, SOCIAL AND JURIDICAL REALITY
}

\author{
I. F. Moldovan
}

\section{Iosif Florin Moldovan}

Faculty of Law, "Vasile Goldiş" Western University of Arad, Romania

* Correspondence: Iosif Florin Moldovan, 16 Alecu Russo St., Dej, Cluj County, Romania E-mail: gerulaflorin@yahoo.com

\begin{abstract}
The family is a biological reality entailed by the union between a man and a woman and by procreation; it is a social reality, given the community of life between the spouses, between parents and children and, generally, between the family members; last but not least, it is a legal reality, by way of the legal regulations regarding the family.

In a narrow sense, the notion of the family includes the spouses and their minor children. In a broader sense, the notion of the family would mean the genealogical tree that includes the totality of the persons descended from a common author, to whom are added the spouses of those persons.

A precise and rigorous definition of the notion of family is hindered by many difficulties, simply because it is an object of research in various and numerous sciences, such as sociology, psychology, law, medicine, etc., each trying to capture its characteristic aspects from their particular angles. The motivation? The legislators themselves are not consistent in establishing a legal definition of the family, providing this notion with an array of different meanings.

In this paper, we will attempt to outline and account for these realities of the family from a legal standpoint, as evinced by various statutory regulations in this field.

Keywords: family, reality, spouses, sciences, children, persons, legislators

\section{Introduction}

Comprehensive meanings of the concept of family are to be found mainly in special laws. Thus, according to Law no. 114/1996," as amended by EO No. 40/19772, "the family (...) means the husband, the wife, the minor and major children and the parents of the spouses who live and share a household together. "The meaning of the notion is relatively similar in Law no. 5/1973 (repealed by Law no. 114/1996), with the difference that insofar as the spouses' parents are concerned, the legislation requires that they "be maintained" by their children ${ }^{3}$.

It is to this category that Law no. 67/1995 on social welfare ${ }^{4}$ also belongs: under the provisions of Art. 2 paragraph 2, the term family also refers to an unmarried person who lives together with his or her child.
\end{abstract}

\section{The members and functions of the family.}

\footnotetext{
${ }^{1}$ Published in the Official Gazette of Romania, P. I, no. 254 of 21 October 1996, Art. 17 and republished in the Official Gazette of Romania, P. I, no. 393 of 31.12.1997.

${ }^{2}$ Published in the Official Gazette of Romania, P.I, no. 154 of 14.07.1977, Art. 1 point 7.

${ }^{3}$ Published in the Official Gazette of Romania, no. 47 of 31.03.1973, Art. 15 para 2.

${ }^{4}$ Published in the Official Gazette of Romania, P. I, no. 279 of 29.11.1995, Art. 2.
} 
The members of the family. The family ${ }^{5}$ is based on the freely consented marriage between the spouses, on their equality and on the parents' right and duty to ensure the upbringing, education and formation of their children (Art. 44 Section 1 of the Romanian Constitution). Children born out of wedlock are equal, before the law, with those born in wedlock (Art. 44 Section 3 of the Romanian Constitution). Children and youth enjoy a special protection and assistance regime as regards the achievement of their rights (Art. 45 Section 1 of the Romanian Constitution). Persons with disabilities enjoy social protection (Art. 46 Section 1 of the Romanian Constitution).

Parents have the right to ensure, according to their own beliefs, the education of their minor children, for which they are responsible (Art. 29 Section 6 of the Romanian Constitution).

The functions of the family. The family fulfills a set of functions for itself and for society, ranging from the biological, natural function of procreation and child rearing, to the manifold internal functions of the family group, of household managing and living in common, of behaving and acquiring the skills for moral and material solidarity between the family members, and to the important social functions of educating and training the children for their normal integration into society. ${ }^{6}$

The family performs the following functions:

A) The function of perpetuating the human species

From the prehistoric emergence of the family by groups to the contemporary monogamous family, the process of perpetuating the human species has taken place primarily within the family, not outside it.

The biological function of the family can, to some extent, be influenced by society.

Population growth directly depends on the demographic structure of society, the structure of various social organisms and the society's birth-rate related policies. In this regard, some countries promote a policy of stimulating birth rates, while others attempt to prevent population growth.

The stimulation and support of birth-rate growth is achieved primarily by legal means and socio-economic measures.

B) The educational function

In all historical periods, the family has played a determining role in the children's education. Within the family, education is mainly aimed at the formation of the child's character and personality, ensuring its growth, physical and spiritual development, the acquisition of skills and essential characteristics, outlining thus its future moral and social profile $^{7}$. The atmosphere in the family, the examples it witnesses, the education and training it receives are preserved in the child's mind for the rest of its life and are decisive in shaping its future character and personality ${ }^{8}$. The parents are bound to raise their child, tending to its health and physical development, education and professional training, according to its characteristics, so that the child may become useful to the community. In addition, Art. 29 Section 6 of the Romanian Constitution enshrines the parents' right to ensure, according to their own beliefs, the education of their minor children, for which they are responsible.

Through their way of life and their attitude towards work and society, parents implicitly have the duty to be a positive example for their children and a model of behavior in the family and society. ${ }^{9}$

\footnotetext{
${ }^{5}$ Ioan Trifa, Florin I. Moldovan, Curs de Dreptul Familiei, Cluj Napoca: “Cordial Lex” Publishing House, 2012, p.5 et seq.

${ }^{6}$ I. Albu, Dreptul familiei, Bucharest: “Didactică şi Pedagogică” Publishing House, 1975, p. 8.

${ }^{7}$ I. Albu, op. cit., p. 13.

${ }^{8}$ Ibidem, p. 13.

${ }^{9}$ M. Banciu, Dreptul familiei, Cluj-Napoca: “Argonaut” Publishing House, 1995, p. 8.
} 
The family has an educational role also as regards the parents and its adult members, because it develops family cohesion and solidarity, the sense of responsibility for the happiness of others, the custom of living in common and the consciousness of fulfilling the family and social duties.

C) The economic function

This finds its expression in the spouses' jointly owned property regime and in their legal duty of maintenance in cases specially provided by the law.

The economic function of the family differs from one society to another and is influenced by the degree of the economic and social development of society.

\section{Family legislation}

In the old Romanian statutes, the family was not defined as a distinct institution. Thus, in the Ipsilante Code (Pravalniceasca Condică) of 1780-1817, the Andronachi Donici Code of 1814-1817, the Caragea Code of 1817-1832 and in others, up until the Constitution of 1866, there were legal provisions relating to "the man and his woman," "for parents and their offspring," "family council," or institutions such as marriage or betrothal. However, the importance of the family institution required the separation of a distinct branch of the legal science, which would regulate family relations: Family Law. In our system of law, Family Law did not appear suddenly, through the implementation of the Family Code. On the contrary, its appearance was marked by a series of enactments, which, in their sequence, outlined its branching off from Civil Law.

The starting point of this evolution was the Constitution of 1948, which included provisions in the field of family relationships, especially those relating to the equality between man and woman.

The Constitution of 1952 gave the possibility for the consecration of Family Law as an independent branch of law.

Family Law provisions were also included in the Constitution of 1965, republished in 1986. Also, the Constitution of 1991, republished in 2003, contains Family Law provisions. The appearance of the Family Code adopted by Law no. 4 of 04.01 .1954 modified the overall conception of the family institution and, especially, of the members it includes. Over time, it was amended and completed, up until 2011, when with the enactment and entry into force of the new Civil Code, the Family Code was repealed. The new law radically changed the overall outlook on civil matters, choosing the model of European codes to incorporate all the provisions concerning persons and family relations.

\section{Family Law. Its concept and object.}

The definition of Family Law.

Family Law represents the totality of the legal provisions governing the personal and property relations entailed by marriage, kinship, adoption and similar relations assimilated by the law, in some respects, with family relationships, for the purpose of protecting and strengthening the family. ${ }^{10}$

\section{The object of Family Law}

Family Law comprises regulations governing family relationships, as follows:

a) Marriage relationships. The provisions of Art. 44 Section 1 of the Romanian Constitution establish that the family is based on the freely consented marriage between the spouses, the personal and property relations between spouses, as well as the conclusion, annulment, termination and dissolution of marriage.

\section{b) Kinship relationships}

Kinship is of two types: blood kinship, which is based on the blood relation between several persons, either of direct lineal descent and ascent or of collateral consanguinity, and affinal kinship, resulting from the act of marriage or of adoption. ${ }^{11}$

\footnotetext{
${ }^{10}$ I.P. Filipescu, Tratat de dreptul familiei, Bucharest: “All” Publishing House, 1993, p. 6.

${ }^{11}$ Republished in the Official Gazette of Romania P. I, no. 276 of 24.07.1998.
} 
c) Relations regarding parental care.

This type of relations consists of the entire sum of the parents' legal rights and obligations to fulfill the personal and property interests of their children.

family

d) Some relationships are assimilated, under the law, in certain respects, with relationships.

This category may include:

- spousal maintenance obligation;

- the maintenance obligation to the spouse who helped with the child maintenance of the other spouse;

- the relations arising in connection with the protection of minors;

- guardianship and trusteeship.

5. The general principles of Family Law

The principle of the state-protection offered to marriage and the family. (Art. 258 paragraphs 2 and 3 of the Civil Code)

The state protects marriage and the family through economic and social measures.

The protection of marriage and the family is achieved not only under the provisions of Family Law, but also under other legal rules. Thus, Art. 44 Section 2 of the Romanian Constitution provides that the conditions relating to the conclusion, dissolution and annulment of marriage are regulated by law. Moreover, the protection of marriage is achieved through the equality between the spouses, their relationships with the children and the maintenance obligations that spouses owe each other.

The principle of monogamy. Art. 273 of the Civil Code establishes that "the man who is married or the woman who is married shall not marry," which means that a valid marriage can be concluded only between unmarried persons, in other words, that the future spouses must be, depending on the situation, single, widowed or divorced.

The legal violation of the monogamy principle, which, in our country, is a principle of public order, is punishable by Art. 293 paragraph 1 of the Civil Code, entailing the absolute nullity of the second or subsequent marriages, and imprisonment for offenses of bigamy -stipulated in and punishable under Art. 303 of the Criminal Code - or of adultery, stipulated in and punishable under Art. 304 of the Criminal Code.

The principle of the freely consented marriage between the spouses This principle is enshrined in the provisions of Art. 48 Section 1 of the Romanian Constitution and Art. 258 paragraph 1, Art. 259 paragraph land Art. 271 of the Civil Code, which stipulate that the family is based on the marriage between the spouses.

Consent to marriage is free, meaning that all racial, religious and legal restrictions to choosing one's spouse have been removed: making marriage conditional upon the approval of others, including of parents, is utterly excluded.

The principle of equality between the spouses Under the provisions of Art 258 paragraph 1 of the Civil Code, the man and the woman have equal rights as regards spousal relations and the exercise of the rights over the children.

The principle of prohibiting marriage between persons of the same sex. (Art. 258 paragraph 1 of the Civil Code).

Art. 277 paragraph 1 of the Civil Code categorically establishes that "the marriage between persons of the same sex is prohibited."

The principle of the spouses granting mutual moral and material support to each other and to the other family members.

This principle is enshrined in several provisions of the Civil Code: Art. 309 paragraph 1, Art. 325 paragraph 1, Art. 261, Art. 483 et seq., Art.513 et seq.

As a rule, moral and material support is provided voluntarily. Exceptionally, material provision can be obtained if necessary, by legal means.

The principle of choosing the applicable matrimonial regime. 
Spouses can currently organize their own property relations and the property relations between them and third parties, according to the specific situation of each family and their own desires and interests, being free to choose one of the matrimonial regimes provided by Art. 312 of the Civil Code.

The principle of the child's best interest.

This principle is governed by Art. 263 of the Civil Code, Art. 6 letter a of Law no.272/2004 governing the protection and promotion of the child's rights, as later amended and supplemented.

This principle is also enshrined in the provisions of Art. 3 paragraph 1 of the Convention on the Rights of the Child, which states: "In all actions concerning children, whether undertaken by public or private social welfare institutions, courts of law, administrative authorities or legislative bodies, the best interests of the child shall be a primary consideration".

\section{The principle of the protection of children and youth}

According to Art. 49 paragraph 1 of the Romanian Constitution, republished, "Children and young people shall enjoy special protection and assistance in the pursuit of their rights".

The principle of equal rights for children.

The principle of the parents' right and duty of to ensure the upbringing and education of their children.

\section{Bibliography}

I. Albu, Dreptul familiei, Bucharest, "Didactică şi Pedagogică" Publishing House, 1975 M. Banciu, Dreptul familiei, Cluj-Napoca, “Argonaut” Publishing House, 1995;

I.P. Filipescu, Tratat de dreptul familiei, Bucharest, "All” Publishing House, 1993

loan Trifa, Florin I. Moldovan, Curs de Dreptul Familiei, Cluj Napoca, "Cordial Lex" Publishing House, 2012

Official Gazette of Romania, no. 47 of 31.03.1973, Art. 15 para. 2 Official Gazette of Romania, P.I, no. 154 of 14.07.1977, Art. 1 point 7. Official Gazette of Romania, P. I, no. 279 of 29.11.1995, Art. 2. Official Gazette of Romania, P. I, no. 254 of 21 October 1996, Art. 17 Official Gazette of Romania, P. I, no. 393 of 31.12.1997. Official Gazette of Romania P. I, no. 276 of 24.07 .1998 . 